\title{
A Comparative Study of Quality of Under Ground Water of Man Tahishil and Phaltan Tahashil Which are Located at aDifferent Height in Satara District From Maharashtra (India)
}

\author{
Dattatraya.D.Virkar \\ Department of chemistry Mudhoji College Phaltan Tal. Phaltan Dist - Satara MS( India)
}

\begin{abstract}
A comparative study of quality of underground water of Man \& Phaltan Tahasil were carried out during the year 2015- 2016.These two Tahasil are located at different heights. The Physico-chemical parameters of water such as $\mathrm{pH}$ electrical conductivity $(E C)$ total hardness $(T H)$ total dissolves solids (TDS) Calcium, magnesium, Sodium and potassium were analyzed. The observed values were compared in between these two Tahasil. It was found from present study that In general the values of the TH, Ca, Mg \& Na were found to higher in Man Tahasil from summer season.
\end{abstract}

Keywords: Comparative Study of ground water of Man \& Phaltan Tahasil.

\section{Introduction}

Water is one of abundantly available substances in nature. It is essential constituent of all animals and plants . It is also required for irrigation agriculture and industrial purpose. Among the various sources of water ground water is safe for drinking and domestic purpose but ground water contains various dissolved salt. Hence quality of ground water is very significant. In present study various samples were collected from two Tahasils which are located at different heights. The samples collected during period of pre- monsoon in the year 20152016 and physico - chemical characteristics has been studies. The chemical analysis was carried out according to procedure stipulated by APHA(1995).The water quality parameter viz pH, Electrical conductance (EC), Total dissolved solids (TDS), total hardness (TH), Calcium(Ca), magnesium ( $\mathrm{Mg}$ ) Sodium ( $\mathrm{Na}$ ) and Potassium (K).

\section{Study Area}

Two Tahasils were selected for study. These two Tahasils are near to each other and separated by Shambhumahadeo Hill Range.The Man Tahasil border is started form top of S.M.hill range and Phaltan Tahasil border is started from bottom of S.M.Hill range. The Man Tahasil is located about 400 meter height from Phaltan Tahasil and this our interest to select these two Tahasil. The man Tahasil is drought prone zone of satara district It lies between. $17^{\circ} 38^{\prime} 24^{\prime \prime} \mathrm{N}$ latitude and $74^{\circ} 46^{\prime} 11^{\prime \prime} \mathrm{E}$ longitudes. The Phaltan Tahasil was partly irrigated and partly comes in drought prone zone It is lies between $17^{0} 58 \mathrm{~N}$ latitude and $74^{\circ} 45^{\prime} \mathrm{E}$ longitude

\section{Experimental}

Ten different places were selected for each Tahasil in order to cover the complete Tahasil. Ground water samples were collected from these ten places of each Tahasil in the month of March and April. In all 20 samples were collected in plastic bottles having capacity of 1 liter. These bottle were village wise labelled for both the Tahasil. The quality of water analyzed in laboratory. The $\mathrm{pH}$ was measured by $\mathrm{pH}$ ep pocket sized $\mathrm{pH}$ meter The conductance was measured by conductivity meter model CM 180 Elicomake. The TDS was measured by TDS meter model EUTECH instrument. The $\mathrm{Na}^{+}$and $\mathrm{K}^{+}$determined by flame photometer of systronic make. The total hardness $\mathrm{Ca}^{++}$and $\mathrm{Mg}^{++}$were analyzed by using standard methods ( APHA-1995) The result obtained from analysis of 10 samples ( M1 to M10) of Man Tahasil are given in table no. 1 and 10 samples ( P1 to P10) of Phaltan Tahasil are given in table No 2

\section{Result and Discussion}

pH: $\mathrm{pH}$ indicates the acidity and alkalinity of water $\mathrm{pH}$ values of ground water of man Tahasil varies from 6.7 to 9.2 that of Phaltan Tahasil varies from 7.2 to 9.0 the average values of Phaltan Tahasil is 7.78 and that of man Tahasil is 8.0.

These values were not so much distinguishable the higher $\mathrm{pH}$ values may be due to accumulation of salt in water.

EC: The Ec values of Man Tahasil varies from 0.6 to 1.34 that of Phaltan Tahasil varies from 0.6 to 1.11 . EC values of Man Tahasil were found to be greater than the Phaltan Tahasil may be due to accumulation of more salt water as Man Tahasil is located higher position than Phaltan Tahasil. 
TDS : TDS of water includes the soluble ionized and non-ionized material the TDS values of man Tahasil were found to so much greater than Phaltan Tahasil.

High TDS is due to discharge of waste water \& which is percolate down to the water table Total hardness (TH) hardness of water is caused due to dissolved metallic ions like $\mathrm{Ca}^{++} \mathrm{Mg}{ }^{++} \mathrm{Sr}^{++} \mathrm{Ba}^{++}$. The TH values of Man Tahasil were found to be so much greater than the Phaltan Tahasil. The high values of TH in man Tahasil can be attributed to low water level it is located above the Phaltan. High concentration of TH causes kidney problem. It is also observed by tentative survey of hospital that numbers of people suffered from kidney stone were found to be greater in Man Tahasil.

Table No. 1

The values of analyzed parameters of Man Tahasil During the year $\quad$ March -April 2015-16

\begin{tabular}{|l|l|l|l|l|l|l|l|l|}
\hline Sample Code & $\mathrm{pH}$ & EC mmhos & TDS mg/L & TH mg/L & Ca++ mg/L & Mg++ mg/L & $\mathrm{Na}+\mathrm{mg} / \mathrm{L}$ & $\mathrm{K}+\mathrm{mg} / \mathrm{L}$ \\
\hline M1 & 8.2 & 0.94 & 810 & 355 & 238 & 117 & 134 & 18.1 \\
\hline M2 & 8.3 & 0.68 & 815 & 325 & 219 & 106 & 112 & 15.1 \\
\hline M3 & 6.7 & 0.81 & 591 & 222 & 124 & 98 & 120 & 22.1 \\
\hline M4 & 7.3 & 1.14 & 622 & 252 & 150 & 102 & 90 & 16.0 \\
\hline M5 & 9.2 & 1.27 & 870 & 326 & 190 & 136 & 110 & 13.2 \\
\hline M6 & 7.8 & 1.17 & 780 & 380 & 253 & 127 & 105 & 19.1 \\
\hline M7 & 6.9 & 1.34 & 980 & 402 & 212 & 190 & 132 & 12.21 \\
\hline M8 & 8.0 & 1.0 & 852 & 295 & 142 & 153 & 118 & 16.0 \\
\hline M9 & 7.3 & 1.14 & 940 & 320 & 214 & 106 & 152 & 13.3 \\
\hline M10 & 8.1 & 1.28 & 985 & 370 & 260 & 110 & & 138 \\
\hline
\end{tabular}

M1 to M10 Water samples of Man Tahasil

Table No. 2

The values of analyzed parameters of Phaltan Tahasil During the year $\quad$ March -April 2015-16

\begin{tabular}{|c|c|c|c|c|c|c|c|c|}
\hline Sample Code & $\mathrm{pH}$ & EC mmhos & TDS mg/L & $\mathrm{TH} \mathrm{mg} / \mathrm{L}$ & $\mathrm{Ca}++\mathrm{mg} / \mathrm{L}$ & $\mathrm{Mg}++\mathrm{mg} / \mathrm{L}$ & $\mathrm{Na}+\mathrm{mg} / \mathrm{L}$ & $\mathrm{K}+\mathrm{mg} / \mathrm{L}$ \\
\hline $\mathrm{P} 1$ & 8.1 & 1.06 & 600 & 220 & 140 & 80 & 85 & 19.5 \\
\hline $\mathrm{P} 2$ & 7.3 & 0.78 & 450 & 200 & 110 & 90 & 67 & 22 \\
\hline P3 & 7.4 & 0.72 & 475 & 190 & 110 & 80 & 70 & 26.1 \\
\hline $\mathrm{P} 4$ & 8.3 & 0.98 & 640 & 250 & 150 & 100 & 90 & 14.2 \\
\hline P5 & 9.0 & 0.85 & 580 & 210 & 120 & 90 & 82 & 18.0 \\
\hline P6 & 8.2 & 0.76 & 560 & 205 & 108 & 97 & 80 & 16.2 \\
\hline P7 & 7.2 & 0.68 & 467 & 190 & 102 & 88 & 71 & 14.8 \\
\hline P8 & 8.4 & 0.90 & 620 & 230 & 140 & 80 & 88 & 22.8 \\
\hline P9 & 8.0 & 0.6 & 550 & 208 & 90 & 118 & 78 & 16.4 \\
\hline P10 & 8.2 & 0.91 & 610 & 212 & 118 & 94 & 88 & 19.2 \\
\hline
\end{tabular}

P1 to P10 Water samples of Phaltan Tahasil

Calcium and magnesium: These are common constituents of natural water and which causes hardness of water the values of calcium and magnesium were found to higher in man Tahasil may be due to evaporation of water content and accumulation of salt.

Sodium and potassium: The concentration of sodium was found to be greater in man Tahasil due to evaporation of water the values of potassium were found to be slightly greater in Phaltan Tahasil.

\section{Conclusion}

The values of EC,TDS, TH, Ca, Mg and $\mathrm{Na}$ were found to be greater in Man Tahasil than the Phaltan. These higher values may be due Man Tahasil is located 400 meter height above the Phaltan Tahasil and due that summer season is sevier in Man Tahasil hence rate of evaporation of water is greater in Man Tahasil.

\section{References}

[1]. APHA standard methods for the examination of water and waste water $19^{\text {th }}$ ed $(1995)$

[2]. N.B.Y. Reddy and K.S.S. Prasad Journal of IAEM, 32(2), 64-73 (2005)

[3]. S. L. Davis and R.J.M. De Wiest Hydrology Johmwielly and sons Inc, New York (1996)

[4]. Chhaya V. WaghsundarhanJ.KokateHaribhau R Aheretal RasayanJ.Chem.2(1), 234 (2009)

[5]. Dattatray D.Virkar AIJR FANS 12 ( 1), 2015 PP 46-48

[6]. Mahesa NagarajNaik and Rajendra Prasad Indian journal of Environmental protection $24(12), 897$ ( 2004)

[7]. C.K. Jain K.K.S Bhatia and T Vijay Ind. J Environmental Health 39(3). 182 ( 119-131)

[8]. Pawar N. J. GeolSoc of India 199341 pp (119-131)

[9]. Ravindra Kumar fundamentals of historical geology and stratigraphy of India New Delhi wileyEstern Ltd.1988.

[10]. Carter HJ. Geology of island of Bombay J. Bombay Branch \& Asiatic Soc 1852 4:1-53

[11]. Sarala C, Ravi Babu P, International journal of scientific and research publications Vol 2 (10), $\mathrm{pp}^{1-6} 2012$

[12]. Sanjay Gupta Akhaleshkumaretal "journal of Environmetal Science and Engineering 2004, 46 (1) 74-78

[13]. N. J. Pawar J. Geol. Soc. Of India. 41,P,119(1993) 